\title{
The role of histochemistry in increasing objectivity in histopathology
}

\author{
A. G. E. Pearse \\ M.A., M.D., F.R.C.P., D.C.P., F.R.C.Path. \\ Department of Histochemistry, Royal Postgraduate Medical School, London W12 0HS
}

\begin{abstract}
Summary
The techniques of microscopic histochemistry, successfully applied to problems in histopathology, necessarily result in increased objectivity.

Combined with procedures for quantification the increase may be such as to remove subjective judgment altogether.

Extended to the ultrastructural level the quality of the information derived is greatly enhanced in terms of localization but there is usually no increase in objectivity.

Of all branches of technology capable of conferring on histopathology an increase in objectivity, histochemistry must take first place.
\end{abstract}

\section{Historical introduction}

Pathology owes to histochemistry more than just an increase in objectivity. The acknowledged founder of the science (or technology) of histochemistry was the French botanist and microchemist F-V. Raspail. In the early 1820's microchemistry meant microscopical chemistry and Raspail, formulating his view of the cell as a laboratory (la cellulelaboratoire), was truly one of the originators of the Cell Theory. His treatise on the development of starch in wheat grains (1825) was headed by an epigram afterwards made famous, without acknowledgment of course, by Rudolf Virchow (1858): 'Omnis cellula e cellula'.

Virchow derived much of his knowledge of the cell and its internal functions directly from the published works of Raspail. Another who did so was Theodor Schwann, regarded by many as the father of the Cell Theory, and not only without acknowledgment but with a contemptuous dismissal of Raspail and his claims as a serious scientist (1839).

\section{Introduction}

After these early exercises there was a long interval, of more than 100 years, when the contributions of microchemistry or histochemistry to the increase of objectivity in histopathology were virtually non-existent. Existing histochemical techniques were few, and the production of excitingly different colours by the histological application of aniline dyes was found altogether more attractive. The position is now completely changed. Many hundreds of thoroughly proved histochemical techniques are available, in well documented form, for the attention $\vec{\omega}$ and use of pathologists.

\section{Basic considerations}

Histochemistry can be defined as the identifica- -7 tion, localization and quantification, in cells ando tissues and by chemical or physical tests, of specific substances, reactive groups and enzyme-catalysed ${ }^{\prime}$ activities'. Taking the first of these functions only, it ${ }^{\infty}$ would appear self-evident that successful identification of a cell component, or metabolite, must ${ }^{-}$ necessarily result in increased objectivity. The philosopher's stone of applied histochemistry in the field of neoplasia, for instance, must be revelation of the quality of malignancy. No one would be bogd $\vec{i}$ enough to state categorically that this ideal is u通- ov attainable. It remains for the present in the categefy' of 'difficult but not impossible'.

Taking the second function, localization, into consideration, it might be thought that its contri-o bution to objectivity in histopathology would be⿳⺈ minimal. Of course this is largely true at the cellular@ level since it is essentially the quality, rather than the $\overrightarrow{0}$ distribution of any particular entity, which confers the 3 property desired. Nevertheless, and particularly at the level of electron microscopical cytochemistry, localization may become increasingly important as ao factor in raising objectivity.

The third function, quantification, would be considered by many to be the most important of the three. In academic terms this may be so but it is easy to show that in the majority of cases involving the successful application of cytochemical techniques음 in the field of histopathology the effect of quantifica- $\rightarrow$ tion is merely to refine the degree of objectivity‥ achieved, and perhaps also to reduce the degree of subjective after-appraisal to the lowest possible level.

\section{Effective techniques for applied histochemistry}

Techniques potentially useful in histopathologye fall into five principal divisions: analytical, auto- $\mathbb{\Phi}$ radiographic, amine fluorescent, immunohisto-? chemical and enzyme histochemical. Probably the most significant and successful applications fall into $\frac{\text { Oे }}{\mathbb{D}}$ one or other of the last three categories. 


\section{Analytical methods}

A substantial part of the whole armamentarium of histochemistry is included in this category. It includes all the methods for proteins and protein end groups, carbohydrates, nucleic acids, lipids, pigments and inorganic substances. It is not difficult to find objectivity-increasing examples in each one of these subdivisions. Simple diagnostic procedures, such as the positive identification of pigment, mucins, lipids and glycogen provide the requisite increase in a wide variety of disorders. As a single important example one may quote the demonstration of sulphatides in peripheral nerve biopsies in metachromatic leucodystrophy (Olsson and Sourander, 1969).

\section{Autoradiography}

Very significant results have been obtained by the use of autoradiographic procedures in the investigation of problems in biology and pharmacology. In pathology there are fewer examples of their diagnostic application, the most outstanding being in the field of cytogenetics. The technique of EM autoradiography (Caro and Palade, 1961) found useful in experimental pathology, has not yet found significant application in terms of diagnosis.

\section{Amine fluorescence}

These techniques, known alternatively but not completely accurately as formaldehyde-induced fluorescence (FIF), stem from early observations by Eränkö $(1951,1952)$ on the production of fluorophores from noradrenalin in the adrenal medulla. As described by Falck et al. (1962) the FIF technique has been widely applied by biological scientists but, again, less widely by pathologists. With or without concomitant microspectrofluorometry the FIF technique has considerable value in the diagnosis of malignant melanomas (Rost and Polak, 1969; Rost, Polak and Pearse, 1973), carcinoids and phaeochromocytomas.

\section{Immunofluorescence and immunoperoxidase methods}

Between them these two facets of immunohistochemistry can bring about a greater increase in histopathological objectivity than all the techniques of the remaining divisions. From the earliest days of immunofluorescence (Coons, Creech and Jones, 1941), to the more recent use of immunoperoxidase methods (Nakane, Sriram and Pierce, 1966), throughout the whole of pathology no field remains untouched. Bacteriology, virology, parasitology are all served by the positive identification of causative organisms in cells and tissues. The immunology of disorders of antibody-forming systems relies heavily on the techniques of immunofluorescence as does my own work on the identification of peptide hormone-producing tumours or apudomas (Pearse and Welbourn, 1973; Pearse and Polak, 1974). A beginning has been made in the use of immunohistochemical techniques for identification of nonendocrine tumours and the extension of this can be predicted with confidence.

\section{Enzyme methods}

Great expectations were aroused, with the enormous technological explosion which took place in this field in the 1950's and early 1960's, that enzyme histochemistry would revolutionize histopathology. To a large extent these expectations await satisfaction and the hoped-for increase in histopathological objectivity is still a long way from fulfilment. Isolated examples are available in plenty but these serve only to emphasize the general sense of failure. Studies with aminopeptidases (Willighagen and Planteydt, 1959) gave early promise of usefulness in the distinction of metastatic tumours of gut origin, and in fibroblastic neoplasias in bone and soft tissues the use of a battery of hydrolases has proved distinctly useful (Jeffree, 1972). One of the oldest histochemical enzyme techniques, for the so-called DOPA oxidase, is still usefully applied in the diagnosis of melanomas, and an equally ancient technique for peroxidase, in modern form, provides useful distinction between myeloblastic and lymphoblastic leukaemias.

\section{Conclusion}

Histopathology can be transformed by the application of any technology which confers upon its observations an increase in objectivity. Foremost in the field comes histochemistry, for a variety of reasons. These include sheer breadth of scope and overwhelming numerical superiority in respect of techniques.

Quantification, perhaps the second most important technology in the present context, is applicable equally to the results of applied histochemistry as to those of pure morphology. There has been, in recent years, a dramatic increase in the availability of instruments for increasing objectivity. These range from simple microdensitometers, cytophotometers and fluorometers, to machines capable of scanning large areas and numbers of cells, and of integrating the results and subjecting them to computer analysis.

Electron microscopy, still the Cinderella of the three in its application to histopathology, will doubtless make an increasing contribution in future years. Electron cytochemistry, its handmaiden, may play a supporting role but their increasing use is to a great extent prevented by their expensiveness in terms of time as well as of individual effort.

Histochemistry, on the contrary, is inexpensive in terms of time, effort and money. It is impossible to apply a single histochemical technique to a problem 
in histopathology without gaining an increase in objectivity. At the same time the element of interpretation is not always altogether removed so that a degree of subjectivity is retained. Objectivity is doubtless a very fine thing-but subjectivity is the spice of life.

\section{References}

Caro, L.G. \& Palade, G. (1961) The role of the Golgi apparatus in the secretory process. Autoradiographic study. Compte rendu des séances de la Société de biologie, 155, 1750.

Coons, A.H., Creech, H.J. \& Jones, R.N. (1941) Immunological properties of an antibody containing a fluorescent group. Proceedings of the Society for Experimental Biology and Medicine, 47, 200.

ERÄNKÖ, O. (1951) On the histochemistry of the rat adrenal medulla. Acta physiologica scandinavica, 25, Suppl. 89, 22.

ERÄNKö, O. (1952) On the histochemistry of the adrenal medulla of the rat, with special reference to acid phosphatase. Acta anatomica, 16, Suppl. 17, 1.

Falck, B., Hillarp, N.Å., Thieme, G. \& Torp, A. (1962). Fluorescence of catecholamines and related compounds condensed with formaldehyde. Journal of Histochemistry and Cytochemistry, 10, 348.

JefFree, G.M. (1972) Enzymes in fibroblastic lesions. Journal of Bone and Joint Surgery, 54B, 535.

Nakane, P.K., Sriram, J. \& Pierce, G.B. (1966) Enzymelabelled antibodies for light and electron microscopic localization of antigens. Journal of Histochemistry ar Cytochemistry, 14, 789.

Olsson, Y. \& Sourander, P. (1969) The reliability of the diagnosis of metachromatic leucodystrophy by periphere. nerve biopsy. Acta paediatrica scandinavica, 58, 15.

Pearse, A.G.E. \& Polak, Julia M. (1974) Endocrine tumouef of neural crest origin: neurolophomas, apudomas, and the APUD concept. Medical Biology, 52, 3.

Pearse, A.G.E. \& Welbourn, R.B. (1973) The apudoma@ British Journal of Hospital Medicine, 10, 617.

Raspail, F.V. (1825) Développement de la fécule dans les organes de la fructification des céréales. Annales d్ㅗ sciences naturelles, 6, 224.

Rost, F.W.D. \& PolaK, Julia M. (1969) Fluorescence micr8 scopy and microspectrofluorimetry of malignant melang mas, naevi and normal melanocytes. Virchows Archiv fin pathologische Anatomie und Physiologie und für klinisc扂. Medizin, 347, 321.

Rost, F.W.D., Polak, Julia \& Pearse, A.G.E. (1973) The cytochemistry of normal and malignant melanocytes, and their relationship to cells of the endocrine polypeptide (APUD) series. Proceedings of the VIIIth Internationd Pigment Cell Conference, Sydney 1972. Pigment Cell, $\$$ 55.

SCHWANN, TH. (1839) Mikroskopische Untersuchungen üben die Übereinstimmung in der Struktur und dem Wachstum der Thiere und der Pflanzen. Berlin.

Willighagen, R.G.J. \& Planteydt, H.T. (1959) Aming peptidase activity in cancer cells. Nature, 183, 263. 